\title{
Nutritional Adequacy of the Daily Stuff at the University Canteens: The Case of a Philippine University
}

\author{
Milagros C. Suyu \\ Andrews Campus, Cagayan State University, Tuguegarao City, Cagayan, Philippines \\ Email address: \\ milasuyu2000@yahoo.com

\section{To cite this article:} \\ Milagros C. Suyu. Nutritional Adequacy of the Daily Stuff at the University Canteens: The Case of a Philippine University. International \\ Journal of Nutrition and Food Sciences. Vol. 5, No. 3, 2016, pp. 160-169. doi: 10.11648/j.ijnfs.20160503.12
}

Received: March 3, 2016; Accepted: March 25, 2016; Published: April 16, 2016

\begin{abstract}
One of the services that a college or university offers to her students is food service. The school canteen can serve as an avenue for developing proper food habits, supporting nutrition education and observing table etiquette. The school canteen can also help reduce nutritional problems by offering and promoting a good selection of economical but nutritious, palatable and sanitary foods. The purpose of this study is to determine the nutritional qualities of the foods regularly sold and consumed by the students and employees at the school canteens. Ten snack items were subjected to analysis to determine their calorie and nutritive values. The study revealed that most of the snack foods do not meet at least one-fifth of the recommended energy and nutrient intake (RENI) for adolescents ages 16 to 18 years for calories, proteins, thiamin, riboflavin, niacin, calcium and iron. It is suggested that regular evaluation of nutritional qualities of food be conducted to ensure the consumption of wholesome food leading to improved health and well-being.
\end{abstract}

Keywords: University Canteens, Daily Stuff, Nutritional Adequacy, Nutritional Analysis, Snack Items

\section{Introduction}

One of the services that a college or university offers to her students is food service. The school canteens can serve as an avenue for developing proper food habits, supporting nutrition education and observing table etiquette. In addition, it can help reduce nutritional problems by offering and promoting a good selection of economical but nutritious, palatable and sanitary foods.

Food is one of the most basic needs of man. It is an integral part of the school life. University canteens are selling different kinds of foods ranging from a wide array of snack items to main dishes that include meat, fish, poultry and vegetable dishes.

College students consist mainly of adolescents. Eating right at this time is important because the body needs a variety of vitamins and minerals to grow, to develop, to stay healthy and to perform well in class. It is therefore important that the small amount of food and drink consumed by the students are rich in nutrients, fiber and calories.

Students' time is spent mostly in school, and so students take most, if not all, of their meals in the school canteens.
Due to economic reasons, some of the students go for snacks, which is generally cheaper than lunch, for them to satisfy their hunger. Snacks are not necessarily bad, especially if they are eating healthy and nutritious food. By eating the proper amount and type of food, students can get the nutrients and calories they need for physiologic and academic functioning. It is therefore important that teachers, administrators, canteen owners and students work together to support a whole-school-approach to building a school culture in which students actively choose nutritious foods for a healthy lifestyle.

The awareness of what and how much food an individual consumes is crucial in achieving and maintaining a healthy body. Foods available in the university canteens show a great variation in terms of the ingredients and manner of preparation. To date, there have been no studies conducted on assessing the nutritive value per serving portion of the foods sold in the school canteens. It is for this reason that the researcher deemed it necessary to evaluate the nutritional adequacy of foods sold in one of the state universities in Cagayan Valley, Philippines.

The importance of studies along school food service is illustrated in the following: For many students who use the 
canteen regularly, every food they buy makes a significant contribution to their total daily food requirement. For those students who do not use the school canteen or food service regularly, the university canteens play important role in educating the thus creating a culture of healthy eating

\subsection{Objectives}

The study aimed to evaluate the calorie and nutritive values of the foods sold at university canteens.

Specifically, the study attempted to achieve the following objectives:

1. To assess the calories, proteins, vitamin B1(thiamine, vitamin B2(riboflavin), niacin, calcium and iron of the snack items regularly consumed by the students.

2. To analyze the \% RENI contributed by these foods to the daily needs of adolescents.

3. To identify the most concentrated sources of calories, protein, vitamin $\mathrm{B} 1$, vitamin $\mathrm{B} 2$, niacin, calcium and iron among the snack items.

4. To assess the proximate calorie, carbohydrate, protein and fat components of the students' lunch or dinner.

5. To identify programs or projects to be implemented to help improve the food service of the university canteens.

6. To promote long-term eating habits, food preferences and attitudes towards food.

\subsection{Related Literature}

In order to function well, the human body must have adequate calories and nutrients. The nutrients known to be essential for human beings are proteins, carbohydrates, fats, minerals, vitamins and water. In addition, foods consumed must also be sanitary and palatable.

College students belong mainly to the adolescence group. During this period, nutrition is very important. It is a time when getting proper nutrition is not always easy. The pace for teens is fast and getting faster. Added to pressures from school to prepare for a job, many students take part in extra and co-curricular activities, sports and physical education classes and some even work part-time for them to go to college.

College students spend most of their time in school, and so most of their meals, if not all of their meals, are taken in school. For the benefit of everyone, students can buy foods at affordable prices to help them stretch their budget.

Snacking is part of student life. It is associated with positive academic outcomes such as improved school performance among students. Many people can benefit from eating snacks especially those who could not take large portions during mealtime. Snacks can provide what may be missing from their meals. It can give them the energy they need to help fuel their body between meals.

Many snacks, such as those offered in fast foods such as burgers and potato fries have high levels of fat, whereas floats and sundaes are rich in sugar. As observed these items become all-time favorites among teenagers. Healthy eating doesn't mean that a person can't have his favorite foods, but the Dietary Guidelines advise him to be selective when it comes from animal products and hydrogenated vegetables oil.

Adolescents between 16 and 18 are completing their final major growth spurt and are on their way to becoming an adult. To approach the right healthy eating, a person should start eating varieties of foods and get the many nutrients the body needs by choosing a variety of foods from each of the GO, GROW and GLOW groups.

The Food and Nutrition Research Institute (FNRI) has developed a food pyramid, a simple easy-to-follow daily eating guide for Filipinos. The food guide pyramid is a graphic translation of the current "Your Guide to Good Nutrition" based on the usual dietary pattern of Filipinos in general. The usual Filipino diet consists mainly of rice. It contributes the major part of the carbohydrates in the diet together with bread, corn and root crops such as sweet potato, cassava and "gabi" or taro. Therefore carbohydrate-foods are at the base of the pyramid and are for liberal consumption to meet 55 to $70 \%$ of energy needs. A viand is a combination of vegetables and fish or other animal protein sources. The second levels of the pyramid are the vegetables and fruits. The best sources of vitamins and minerals are the leafy greens and vitamin $\mathrm{C}$ rich fruit plus dietary fiber or roughage. The third level consist of animal protein like fish, meat, poultry, seafood, milk and dairy products, as well as dried beans and nuts. These foods are recommended for moderate consumption as they supply high quality protein, vitamins and minerals. Finally, at the tip of the pyramid are the fats and oils that are to be taken just enough. In general, Filipino diet is lacking in fat that's the reason why they have very low calories.

For the Filipino, the Food Guide Pyramid teaches the principle of eating a variety of foods every day at the right amounts. It teaches the importance of other foods like rice and other cereals that occupy the major bulk in the diet, while oils and fats share the least in volume and bulk. Vegetables occupy a bigger area than fruits in volume and bulk. This FNRI Food Guide Pyramid is one of the dietary tools used by Filipinos to help achieve good health and nutrition.

\subsection{Benefits of Snacking}

Snacking has the following benefits: sustaining energy and improving diet quality.

Sustaining Energy

Snacking helps fuel the body to prepare for and recover from exercise and physical activity. Guidelines for glycogen storage stress the value of choosing nutrient-rich high carbohydrate foods along with other foods that provide a good source of protein and other nutrients. These macronutrients may assist in other recovery processes and, in the case of protein, may promote additional glycogen recovery when carbohydrate intake is suboptimal or when frequent snacking is not possible.

Snacking also provides energy during periods of the day when hunger strikes. In one study, those who had eaten a small breakfast spent significantly less time attending to their 
work than those who had eaten larger meals. Consumption of a mid-morning snack reversed the adverse effect of a small breakfast.

Improving Diet Quality

One role for snacking identified by research is the opportunity to add "good-for-you" nutrients to the diet. One study among American adolescents showed that foods consumed as snacks provided $12-39 \%$ of the day's total number of portions from the five My Pyramid food groups. Statistically significant nutrients provided by these snacks included Vitamin $\mathrm{C}$ and carbohydrates, and snacking was positively related to meeting daily milk and oil recommendations. Additionally, snack foods and increased eating frequency have been found to contribute substantial amounts of whole grains, vitamin E, dietary fiber, iron, folate, calcium, magnesium, potassium, and monounsaturated fatty acids to the diets of Americans.

A teenage snack should contain the following:

Calories. The nutrients protein, carbohydrates and fats in food serve as the body's energy sources. Each gram of protein and carbohydrate supplies four calories, or units of energy, whereas fat contributes more than twice as much: nine calories per gram.

Calories are the measurement used to express the energy delivered by food. The body demands more calories during early adolescence than at any other time of life. On average, boys require about two thousand eight hundred calories per day; and girls, two thousand calories per day.

\subsection{Nutrients}

Protein. Proteins are made of amino acids necessary for growth and tissue repair. The best sources of protein include beef, chicken, pork, fish, eggs and cheese. The typical Filipino protein sources include animal foods such as meat like pork and carabeef, fish, poultry, tinapa or smoked fish, dried fish, milk, eggs and legumes.

Carbohydrates. Carbohydrates, found in starches and sugars, get converted into the body's main fuel: the simple sugar glucose. Complex carbs provide sustained energy. What is interesting about carbohydrates is the fiber that goes along with other nutrients. They are truly foods of substance: filling yet low in fat. In choosing the type of carbohydrates for the diet, complex ones like the rootcrops should make up 50 to 60 percent of a teenager's caloric intake. Simple carbs, on the other hand, are immediate sources of energy but have little else to offer and should be minimized in the diet.

Water. Water is indispensable for human survival. Dehydration kills far more quickly than starvation. In order to live, every cell in the body must be bathe in water. Water takes an active part in regulating many chemical reactions and is needed as a transport medium for other nutrients. Sad to say that today many can no longer drink water for free as almost everybody drinks the purified water. With the advent of bottled water, it is hoped that water consumption among humans is not affected.

Dietary Fat. Nutrition experts recommend that fat make up no more than 30 percent of the diet. Fat supplies energy and assists the body in absorbing the fat-soluble vitamins: A, D, $\mathrm{E}$ and $\mathrm{K}$. But these benefits must be considered next to its many adverse effects on health. A teenager who indulges in a fat-heavy diet is going to put on weight, even if he is active.

Fats and oils are the most concentrated sources of energy since a gram of fat yields 9 calories upon oxidation. Fats in the diet are necessary for good health. They make certain vitamins available for use in the body, they cushion vital organs, they make up part of some body cells and they help to maintain body temperature.

Fatty foods contain cholesterol, a waxy substance that can clog an artery and eventually cause it to harden. The danger of atherosclerosis is that the blockage will affect one of the blood vessels leading to the heart or the brain, setting off a heart attack or a stroke. Although these life-threatening events usually do not strike until later in adult life, the time to start practicing prevention is now, by reducing the amount of fat in your family's diet.

Vitamins and Minerals. A balance diet should deliver sufficient amounts of all the essential vitamins and minerals one needs. Adolescents tend to most often fall short of their daily quotas of calcium, iron and zinc, so that some would opt to take vitamin and mineral pills. This is good but it is preferable to obtain nutrients from food instead of from dietary supplements and synthetic pills because unlike supplements and synthetic vitamins and minerals, vegetables, fruits and grains contain phytochemicals which are believed to help safeguard people from diseases.

Minerals are inorganic nutrients that remain as ash when burned or oxidized by the body. Almost all food contributes to a varied intake of essential minerals. Iron helps to build red blood cells. It helps the oxygen from the lungs to reach each body cell. Rich sources of iron are meat especially liver, egg yolks and dark green vegetables. Everyone at every age needs calcium, this mineral builds bones and teeth and it is necessary for blood clotting. The best sources of calcium are milk and hard cheese. Others are leafy greens, nuts and small fishes.

To achieve a healthy body, it is not enough to meet quality. The right amount of each nutrient must also be considered. Figure 1 lists the Recommended Energy and Nutrient Intakes (RENI) for Filipinos. Shown in the figure are the differences in RENI of individuals based on their physiologic grouping.

According to Murphy (2003), snacks are designed to improve nutrient intakes among school-teenagers living in rural Kenya. Snacks containing animal source foods (milk and meat) provided more nutrients than an equicaloric vegetarian snack. Animal foods are rich in calcium, Vitamin A (primarily from fortified cooking fat. The milk snack is rich in calcium, vitamin $\mathrm{A}$ and vitamin $\mathrm{B}-12$, and the meat snack supplied vitamin B-12, iron and zinc.

Another study suggests that snacking helps appetite control by preventing overeating at meals. The authors noted that eating smaller amounts more frequently may be a more compatible pattern of eating than eating large meals for a physically-active lifestyle. One study used NHANES data to determine associations between snacking frequency and 
overweight/abdominal obesity. The study found inverse relationships between snacking frequency and mean body weight, BMI, the percentile of BMI-for-age, and waist circumference among participating adolescents.

\begin{tabular}{|c|c|c|c|c|c|c|c|c|c|c|c|c|}
\hline \multicolumn{13}{|c|}{ Recommended Energy and Nutrient Intakes for Filipinos, RENI } \\
\hline $\begin{array}{l}\text { Population } \\
\text { group }\end{array}$ & $\begin{array}{l}\text { Weight } \\
(\mathrm{kg})\end{array}$ & $\begin{array}{l}\text { Energy } \\
\text { (kcal) }\end{array}$ & $\begin{array}{l}\text { Protein } \\
\text { (B) }\end{array}$ & $\begin{array}{c}\text { Vitamin } A \\
(\mathrm{mg})\end{array}$ & \begin{tabular}{|c|} 
Vitamin C \\
$(\mathrm{mg})$
\end{tabular} & $\begin{array}{c}\text { Thiamin } \\
\text { (mg) }\end{array}$ & \begin{tabular}{|c|}
$\begin{array}{c}\text { Riboflavin } \\
\text { (mg) }\end{array}$ \\
\end{tabular} & $\begin{array}{c}\text { Niacin } \\
(\mathrm{mg})\end{array}$ & $\begin{array}{l}\text { Folate } \\
\text { (ug DFE) }\end{array}$ & $\begin{array}{l}\text { Calcium } \\
(\mathrm{mg})\end{array}$ & Iron (ms) & $\begin{array}{c}\text { Iodine } \\
\text { ( } \mu g)\end{array}$ \\
\hline \multicolumn{13}{|l|}{ Infants, mo } \\
\hline Birth $<6$ & 6 & 560 & 9 & 375 & 30 & 0.2 & 0.03 & 1.5 & 65 & 200 & 0.38 & 90 \\
\hline 6 to 12 & 9 & 720 & 14 & 400 & 30 & 0.4 & 0.4 & 5 & 80 & 400 & 10 & 90 \\
\hline \multicolumn{13}{|l|}{ Children, y } \\
\hline $1 \cdot 3$ & 13 & 1070 & 28 & 400 & 30 & 0.5 & 0.5 & 6 & 160 & 500 & 8 & 90 \\
\hline $4 \cdot 6$ & 19 & 1410 & 38 & 400 & 30 & 0.6 & 0.6 & 7 & 200 & 550 & 9 & 90 \\
\hline 7.9 & 24 & 1600 & 43 & 400 & 35 & 0.7 & 0.7 & 9 & 300 & 700 & 11 & 120 \\
\hline \multicolumn{13}{|l|}{ Males, y } \\
\hline $10-12$ & 34 & 2140 & 54 & 400 & 45 & 0.9 & 1.0 & 12 & 400 & 1000 & 13 & 120 \\
\hline 13-15 & 50 & 2800 & 71 & 550 & 65 & 1.2 & 1.3 & 16 & 400 & 1000 & 20 & 150 \\
\hline $16-18$ & 58 & 2840 & 73 & 600 & 75 & 1.4 & 1.5 & 16 & 400 & 1000 & 14 & 150 \\
\hline $19-29$ & 59 & 2490 & 67 & 550 & 75 & 1.2 & 1.3 & 16 & 400 & 750 & 12 & 150 \\
\hline $30-49$ & 59 & 2420 & 67 & 550 & 75 & 1.2 & 1.3 & 16 & 400 & 750 & 12 & 150 \\
\hline $50-64$ & 59 & 2170 & 67 & 550 & 75 & 1.2 & 1.3 & 16 & 400 & 750 & 12 & 150 \\
\hline $65+$ & 59 & 1890 & 67 & 550 & 75 & 1.2 & 1.3 & 16 & 400 & 800 & 12 & 150 \\
\hline \multicolumn{13}{|l|}{ Females, y } \\
\hline $10-12$ & 35 & 1920 & 49 & 400 & 45 & 0.9 & 0.9 & 12 & 400 & 1000 & 19 & 120 \\
\hline $13-15$ & 40 & 2250 & 63 & 450 & 65 & 1.0 & 1.0 & 14 & 400 & 1000 & 21 & 150 \\
\hline $16-18$ & 50 & 2050 & 59 & 450 & 70 & 1.1 & 1.1 & 14 & 400 & 1000 & 27 & 150 \\
\hline $19-29$ & 51 & 1860 & 58 & 500 & 70 & 1.1 & 1.1 & 14 & 400 & 750 & 27 & 150 \\
\hline $30-49$ & 51 & 1810 & 58 & 500 & 70 & 1.1 & 1.1 & 14 & 400 & 750 & 27 & 150 \\
\hline $50-64$ & 51 & 1620 & 58 & 500 & 70 & 1.1 & 1.1 & 14 & 400 & 800 & 27 & 150 \\
\hline $65+$ & 51 & 1410 & 58 & 500 & 70 & 1.1 & 1.1 & 14 & 400 & 800 & 10 & 150 \\
\hline \multicolumn{13}{|l|}{ Pregnant } \\
\hline \multicolumn{13}{|l|}{ Trimester } \\
\hline First & & & 66 & 800 & 80 & 1.4 & 1.7 & 18 & 600 & 800 & 27 & 200 \\
\hline Second & & +300 & 66 & 800 & 80 & 1.4 & 1.7 & 18 & 600 & 800 & 34 & 200 \\
\hline Third & & +300 & 66 & 800 & 80 & 1.4 & 1.7 & 18 & 600 & 800 & 38 & 200 \\
\hline \multicolumn{13}{|l|}{ Lactating } \\
\hline $1^{\text {st }} 6$ months & & +500 & 81 & 900 & 105 & 1.5 & 1.7 & 17 & 500 & 750 & 27 & 200 \\
\hline $2^{\text {nd }} 6$ months & & +500 & 76 & 900 & 100 & 1.5 & 1.7 & 17 & 500 & 750 & 30 & 200 \\
\hline
\end{tabular}

Fig. 1. Reni for filipinos.

In this same study, prevalence for over-weight/obesity and the occurrence of abdominal obesity decreased as snacking frequency and energy consumed from snacks increased.

A review paper by Gatenby (2003) found that snacking contributes significantly to the nutrient quality of the diet. Although those who snacked frequently tended to eat more food in general, the snack foods were not providing "empty calories"; rather, they were providing important vitamins and minerals. An analysis of the food intake records over a twoday period observed that the largest proportion of vitamin $\mathrm{C}$ and a large proportion of vitamin A intakes were from snacks, which provided $20 \%$ of total daily caloric intake.

While some literature and studies confirm the contribution of snacks to the total day's nutrient needs, there are opposing ideas given by other researchers.
Bliss (2012) believes that snacking is associated with increased calories and decreased nutrients. This belief was supported by the researchers of the Food Surveys Research Group (FSRG) in Beltsville. After examining dietary intake survey data from more than 5,000 adults aged 20 years and older, they found out that snacking habit is associated with increased caloric intake and decreased nutrient intake.

Snacking is a dietary behavior that has increased in recent years. With the many street foods abounding everywhere, one's day is incomplete without having to savor with at least one snack item-juices of all sorts, fish balls, squid balls, calamares, siomai, kwek-kwek, sweet corn, isaw, etc, Food peddlers' presence along college avenues entices your appetite as you view "loyalists" patronizing and enjoying their products. 


\section{Methodology}

\subsection{Research Design}

The major objective of the study was to assess the nutritional adequacy of meals served at university canteens. To determine the calorie and nutrient contents, ingredients of the snack items prepared by the canteen operators were taken through observation and/or interview with the cooks/ food preparers. These snack items were subjected to nutritional evaluation using a self-made recipe evaluation form.

Calorie and nutritive values per 100 grams edible portion (EP) were taken from the Food Composition Table (FCT). These values served as bases in calculating the calorie and nutritive values of the ingredients used in the preparation of the snack items. The formula is:

Calorie/Nutritive value

$=\frac{\text { calorie/nutr.value per } 100 \text { g E.P.x E.P. weight of the sample }}{100}$

Calorie and nutrient values per serving was calculated by dividing the total calorie and nutritive values by the number of servings of the recipe. The formula is:

Calorie/Nutritive value per serving

$$
=\frac{\text { calorie/nutritive value of the recipe }}{\text { No. of servings }}
$$

Percentage Recommended Energy and Nutrient Intakes (\% RENI) was computed using the formula:

$$
\% \text { RENI }=\frac{\text { Cal } / \mathrm{NV} \text { per serving }}{\text { RENI of the specific nutrient }} \times 100
$$

\subsection{Sampling Technique}

In choosing the canteens included in the study, the investigator selected ten (10) stalls from among the twenty (20) stalls in the university. The items selected for evaluation were those that were frequently bought by the students and those that were prepared by the operators themselves. Observation and interviews were used to gather data.

\section{Results and Discussion}

The study evaluated the nutritional adequacy of ten snack items sold at the University Canteens. One snack item each from the ten stalls were taken for nutritional analysis.

\subsection{Snack Items Most Commonly Eaten}

Based on interviews and observation among students, the most commonly eaten snack items are Pancit Guisado, Bihon Guisado, Spaghetti, Mami, Kutsinta, Macaroni Soup, Hotdog on stick, Footlong, Shanghai and Arroz Caldo.

\subsection{Nutritional Adequacy of the Snack Items and the \%RENI Contribution}

Ten snack foods were taken for theoretical evaluation namely Pancit Guisado, Bihon Guisado, Spaghetti, Mami, Kutsinta, Macaroni Soup, Hotdog on stick, Footlong, Shanghai and Arroz Caldo. Calories and nutrients, i.e., protein, vitamin $\mathrm{B} 1$, vitamin $\mathrm{B} 2$, niacin, calcium and iron were calculated using the Food Composition Table (FCT) and the results were compared with the Recommended Energy and Nutrient Intakes for adolescents aged 16-18 years old.

Table 1. Computed Actual Nutrient per Serving of Pancit Guisado and the \% RENI Contribution.

\begin{tabular}{lllll}
\hline \multirow{2}{*}{$\begin{array}{l}\text { Calorie and Nutrients } \\
\text { Evaluated }\end{array}$} & RENI & & \multicolumn{2}{l}{ Pancit Guisado } \\
\cline { 4 - 5 } Calories & $\mathrm{M}$ & 2840 & 174.12 & 6.13 \\
& $\mathrm{~F}$ & 2050 & 174.12 & 8.49 \\
Protein (g) & $\mathrm{M}$ & 73 & 6.34 & 8.73 \\
& $\mathrm{~F}$ & 59 & 6.34 & 10.81 \\
Thiamin (mg) & $\mathrm{M}$ & 1.4 & 4.56 & 11.43 \\
& $\mathrm{~F}$ & 1.1 & 4.56 & 14.81 \\
Riboflavin (mg) & $\mathrm{M}$ & 1.5 & 0.08 & 5.33 \\
& $\mathrm{~F}$ & 1.1 & 0.08 & 7.27 \\
Niacin (mg) & $\mathrm{M}$ & 16 & 1.6 & 10 \\
& $\mathrm{~F}$ & 14 & 1.6 & 11.43 \\
Calcium (mg) & $\mathrm{M}$ & 1000 & 30.51 & 3.05 \\
& $\mathrm{~F}$ & 1000 & 30.51 & 3.05 \\
\hline Iron (mg) & $\mathrm{M}$ & 14 & 1.24 & 8.86 \\
\hline
\end{tabular}

The nutrient that is highest in Pancit Guisado in terms of its \% RENI is thiamin, however, it did not meet at least $20 \%$ of the recommended thiamin intake for the age group. The lowest, as shown in its RENI contribution is calcium. Doubling the serving of Pancit Guisado will meet at least $20 \%$ of the recommended protein for girls, and $20 \%$ of the recommended intake for niacin and thiamin of both sexes.

Table 2. Computed Actual Nutrient per Serving of Bihon Guisado and the \% RENI Contribution.

\begin{tabular}{lllll}
\hline \multirow{2}{*}{$\begin{array}{l}\text { Calorie and Nutrients } \\
\text { Evaluated }\end{array}$} & RENI & & \multicolumn{2}{l}{ Bihon Guisado } \\
\cline { 4 - 5 } Calories & M & 2840 & 307 & \%RENI \\
\hline \multirow{2}{*}{ Protein (g) } & F & 2050 & 307 & 10.81 \\
& M & 73 & 4.88 & 14.98 \\
Thiamin (mg) & F & 59 & 4.88 & 6.68 \\
& M & 1.4 & 0.03 & 8.27 \\
Riboflavin (mg) & F & 1.1 & 0.03 & 2.14 \\
& M & 1.5 & 0.03 & 2.73 \\
Niacin (mg) & F & 1.1 & 0.03 & 2.0 \\
& M & 16 & 0.43 & 2.73 \\
Calcium (mg) & F & 14 & 0.43 & 2.69 \\
& M & 1000 & 24.83 & 3.07 \\
Iron (mg) & F & 1000 & 24.83 & 2.43 \\
& M & 14 & 1.53 & 2.43 \\
\hline
\end{tabular}

Table 2 shows that of the nutrients evaluated, iron was the highest in Bihon Guisado in terms of its percentage contribution to one's daily need. The calories contribute 
about $15 \%$ to the RENI of this age group. Doubling the serving for Pancit-Bihon will supply the $20 \%$ of the calorie and iron needs for the adolescent male.

Table 3 shows that a serving of Spaghetti gives approximately 269.77 calories contributing about $10 \%$ of the energy need of the 16-18 year old adolescent male. Thiamin for female has the highest \%RENI contribution having a percentage of $18.18 \%$ followed by the riboflavin for girls $14.55 \%$

Table 3. Computed Actual Nutrient per Serving of Spaghetti and the \% RENI Contribution.

\begin{tabular}{|c|c|c|c|c|}
\hline \multirow{2}{*}{$\begin{array}{l}\text { Calorie and } \\
\text { Nutrients Evaluated }\end{array}$} & \multirow{2}{*}{ RENI } & & \multicolumn{2}{|l|}{ Spaghetti } \\
\hline & & & Calorie/NV & \%RENI \\
\hline \multirow{2}{*}{ Calories } & M & 2840 & 269.77 & 9.50 \\
\hline & $\mathrm{F}$ & 2050 & 269.77 & 13.60 \\
\hline \multirow{2}{*}{ Protein $(\mathrm{g})$} & M & 73 & 7.08 & 10.25 \\
\hline & $\mathrm{F}$ & 59 & 7.08 & 12.68 \\
\hline \multirow{2}{*}{ Thiamin (mg) } & $\mathrm{M}$ & 1.4 & 0.20 & 14.28 \\
\hline & $\mathrm{F}$ & 1.1 & 0.20 & 18.18 \\
\hline \multirow{2}{*}{ Riboflavin (mg) } & M & 1.5 & 0.16 & 10.67 \\
\hline & $\mathrm{F}$ & 1.1 & 0.16 & 14.55 \\
\hline \multirow{2}{*}{ Niacin (mg) } & M & 16 & 1.90 & 11.88 \\
\hline & $\mathrm{F}$ & 14 & 1.90 & 13.57 \\
\hline \multirow{2}{*}{ Calcium (mg) } & M & 1000 & 41.90 & 4.42 \\
\hline & $\mathrm{F}$ & 1000 & 41.90 & 4.42 \\
\hline \multirow{2}{*}{ Iron (mg) } & M & 14 & 2.10 & 15 \\
\hline & $\mathrm{F}$ & 27 & 2.10 & 7.78 \\
\hline
\end{tabular}

Table 4. Computed Actual Nutrient per Serving of Pancit Mami and the \% RENI Contribution.

\begin{tabular}{lllll}
\hline $\begin{array}{l}\text { Calorie and Nutrients } \\
\text { Evaluated }\end{array}$ & RENI & & Pancit Mami \\
\cline { 4 - 5 } Calories & $\mathrm{M}$ & 2840 & 218.84 & 7.71 \\
& $\mathrm{~F}$ & 2050 & 218.84 & 10.68 \\
Protein (g) & $\mathrm{M}$ & 73 & 6.53 & 8.96 \\
& $\mathrm{~F}$ & 59 & 6.53 & 11.07 \\
Thiamin (mg) & $\mathrm{M}$ & 1.4 & 0.20 & 14.28 \\
& $\mathrm{~F}$ & 1.1 & 0.20 & 18.18 \\
Riboflavin (mg) & $\mathrm{M}$ & 1.5 & 0.02 & 1.3 \\
& $\mathrm{~F}$ & 1.1 & 0.02 & 5.8 \\
Niacin (mg) & $\mathrm{M}$ & 16 & 1.52 & 9.50 \\
& $\mathrm{~F}$ & 14 & 1.52 & 10.85 \\
Calcium (mg) & $\mathrm{M}$ & 1000 & 9.63 & 0.96 \\
& $\mathrm{~F}$ & 1000 & 9.63 & 0.96 \\
\hline Iron (mg) & $\mathrm{M}$ & 14 & 1.83 & 13.07 \\
& $\mathrm{~F}$ & 27 & 1.83 & 6.77 \\
\hline
\end{tabular}

Pancit Mami in Table 4 shows that thiamin has the greatest percentage RENI contribution to the daily diet. The iron of Pancit Mami supplies 13.03 percent of the iron needs of male.It should be noted that the stock used in making Mami is the beef or carabeef bone stock. What nutrients does this stock contain? As the bones cook in water - especially if that water has been made slightly acidic by the inclusion of cider vinegar - minerals and other nutrients leach from the bones into the water. Homemade broth is rich in calcium, magnesium, phosphorus and other trace minerals. The minerals in broth are easily absorbed by the body. Bone broth even contains glucosamine and chondroiton - which are thought to help mitigate the deletorious effects of arthritis and joint pain. Further, homemade bone broths are often rich in gelatin. Gelatin is an inexpensive source of supplementary protein. Gelatin also shows promise in the fight against degenerative joint disease.

Table 5. Computed Actual Nutrient per Serving of Kutsina and the \% RENI Contribution.

\begin{tabular}{lllll}
\hline $\begin{array}{l}\text { Calorie and } \\
\text { Nutrients Evaluated }\end{array}$ & RENI & & Kutsinta & \\
\cline { 4 - 5 } Calories & M & 2840 & 79.37 & \%RENI \\
\hline \multirow{2}{*}{ Protein (g) } & F & 2050 & 79.37 & 3.38 \\
& $\mathrm{M}$ & 73 & 0.78 & 1.07 \\
Thiamin (mg) & $\mathrm{F}$ & 59 & 0.78 & 0.32 \\
& $\mathrm{M}$ & 1.4 & 0.04 & 2.64 \\
Riboflavin (mg) & $\mathrm{F}$ & 1.1 & 0.04 & 3.36 \\
& $\mathrm{M}$ & 1.5 & 0.03 & 2.13 \\
Niacin (mg) & $\mathrm{F}$ & 1.1 & 0.03 & 2.91 \\
& $\mathrm{M}$ & 16 & 0.13 & 0.78 \\
Calcium (mg) & $\mathrm{F}$ & 14 & 0.13 & 0.89 \\
& $\mathrm{M}$ & 1000 & 30.24 & 3.03 \\
Iron (mg) & $\mathrm{F}$ & 1000 & 30.24 & 3.03 \\
\hline
\end{tabular}

A serving of kutsinta here means one piece. It must be noted that a student does not buy a piece of kutsinta. Based on observation the student buys to the minimum 3 pieces. Adding the calorie and nutritive values of three pieces would still result to less than $20 \%$ of the RENI. But consuming about 5 to 7 pieces of this delicacy is enough to provide at least $20 \%$ of the recommended calories, thiamin, riboflavin, and calcium for both sexes. Eating 7 pieces will meet onefifth of the iron need of girls.

Table 6. Computed Actual Nutrient per Serving of Macaroni Soup and the \% RENI Contribution.

\begin{tabular}{|c|c|c|c|c|}
\hline \multirow{2}{*}{$\begin{array}{l}\text { Calorie and } \\
\text { Nutrients Evaluated }\end{array}$} & \multirow{2}{*}{\multicolumn{2}{|c|}{ RENI }} & \multicolumn{2}{|c|}{ Macaroni Soup } \\
\hline & & & Calorie/NV & \%RENI \\
\hline \multirow{2}{*}{ Calories } & $\mathrm{M}$ & 2840 & 62.32 & 2.19 \\
\hline & $\mathrm{F}$ & 2050 & 62.32 & 3.04 \\
\hline \multirow{2}{*}{ Protein $(\mathrm{g})$} & $\mathrm{M}$ & 73 & 2.15 & 2.95 \\
\hline & $\mathrm{F}$ & 59 & 2.15 & 3.64 \\
\hline \multirow{2}{*}{ Thiamin (mg) } & $\mathrm{M}$ & 1.4 & 0.31 & 22.14 \\
\hline & $\mathrm{F}$ & 1.1 & 0.31 & 28.18 \\
\hline \multirow{2}{*}{ Riboflavin (mg) } & $\mathrm{M}$ & 1.5 & 0.05 & 3.3 \\
\hline & $\mathrm{F}$ & 1.1 & 0.05 & 4.55 \\
\hline \multirow{2}{*}{ Niacin (mg) } & $\mathrm{M}$ & 16 & 0.59 & 3.69 \\
\hline & $\mathrm{F}$ & 14 & 0.59 & 4.21 \\
\hline \multirow{2}{*}{ Calcium (mg) } & $\mathrm{M}$ & 1000 & 20.48 & 2.05 \\
\hline & $\mathrm{F}$ & 1000 & 20.48 & 2.05 \\
\hline \multirow{2}{*}{ Iron (mg) } & M & 14 & 5.62 & 40.14 \\
\hline & $\mathrm{F}$ & 27 & 5.62 & 20.81 \\
\hline
\end{tabular}

It is worthy to note that a serving of macaroni soup, that is one cup, meets more than $20 \%$ of the RENI for thiamin and iron for both sexes. Based on the recipe evaluation, the 
greatest contributor of thiamin and iron in the recipe are margarine and milk, respectively. When this soup is ordered with boiled egg, all the nutrients under study are increased.

Table 7. Computed Actual Nutrient per Serving of Hotdog on Stick and the \% RENI Contribution

\begin{tabular}{|c|c|c|c|c|}
\hline \multirow{2}{*}{$\begin{array}{l}\text { Calorie and } \\
\text { Nutrients Evaluated }\end{array}$} & \multirow{2}{*}{\multicolumn{2}{|c|}{ RENI }} & \multicolumn{2}{|c|}{ Hotdog on Stick } \\
\hline & & & Calorie/NV & \%RENI \\
\hline \multirow{2}{*}{ Calories } & M & 2840 & 181.67 & 6.40 \\
\hline & $\mathrm{F}$ & 2050 & 181.67 & 8.86 \\
\hline \multirow{2}{*}{ Protein (g) } & M & 73 & 8.71 & 11.93 \\
\hline & F & 59 & 8.71 & 14.76 \\
\hline \multirow{2}{*}{ Thiamin (mg) } & M & 1.4 & 0.33 & 23.57 \\
\hline & F & 1.1 & 0.33 & 30.00 \\
\hline \multirow{2}{*}{ Riboflavin (mg) } & M & 1.5 & 1.13 & 75.33 \\
\hline & $\mathrm{F}$ & 1.1 & 1.13 & 102.73 \\
\hline \multirow{2}{*}{ Niacin (mg) } & M & 16 & 1.18 & 7.38 \\
\hline & $\mathrm{F}$ & 14 & 1.18 & 8.43 \\
\hline \multirow{2}{*}{ Calcium (mg) } & M & 1000 & 37.25 & 3.73 \\
\hline & $\mathrm{F}$ & 1000 & 37.25 & 3.73 \\
\hline \multirow{2}{*}{ Iron (mg) } & M & 14 & 0.88 & 6.29 \\
\hline & $\mathrm{F}$ & 27 & 0.88 & 3.26 \\
\hline
\end{tabular}

Table 8. Computed Actual Nutrient per Serving of Footlong and the \% RENI Contribution.

\begin{tabular}{lllll}
\hline $\begin{array}{l}\text { Calorie and } \\
\text { Nutrients Evaluated }\end{array}$ & RENI & & Footlong \\
\cline { 3 - 5 } Calories & M & 2840 & 101.19 & 9.20 \\
& Falorie/NV & \%RENI \\
\hline Protein (g) & M & 73 & 11.64 & 15.95 \\
& F & 59 & 11.64 & 20.01 \\
Thiamin (mg) & M & 1.4 & 0.03 & 2.14 \\
\multirow{2}{*}{ Riboflavin (mg) } & F & 1.1 & 0.03 & 2.73 \\
& M & 1.5 & 0.04 & 2.67 \\
Niacin (mg) & F & 1.1 & 0.04 & 3.64 \\
\multirow{2}{*}{ Calcium (mg) } & M & 16 & 1.17 & 7.31 \\
& F & 14 & 1.17 & 8.36 \\
Iron (mg) & M & 1000 & 41.98 & 4.20 \\
\hline & F & 1000 & 41.98 & 4.20 \\
\hline
\end{tabular}

Data on Table 7 reveal that thiamin and riboflavin contents of hotdog on stick met more than $20 \%$ of the RENI for both sexes. It is worthy to note that this snack item meets $102.73 \%$ of the requirement for riboflavin for female and $75 \%$ of the RENI for male. Of all the recipes, hotdog on stick has the highest amount of riboflavin and thiamin

Table 8 shows that only the recommended intake for protein for female was met by a serving of footlong. All the rest fell short of the recommended intakes for calories and the nutrients evaluated. Footlong is not generally eaten alone. It is paired with a bottle of softdrinks. If this is the case, $20 \%$ of the recommended calorie need for the day for females could be supplied by a piece of footlong and a bottle of soft drinks.
Table 9. Computed Actual Nutrient per Serving of Lumpiang Shanghai and the \% RENI Contribution.

\begin{tabular}{|c|c|c|c|c|}
\hline \multirow{2}{*}{$\begin{array}{l}\text { Calorie and Nutrients } \\
\text { Evaluated }\end{array}$} & \multirow{2}{*}{\multicolumn{2}{|c|}{ RENI }} & \multicolumn{2}{|c|}{ Lumpiang Shanghai } \\
\hline & & & Calorie/NV & \%RENI \\
\hline \multirow{2}{*}{ Calories } & $\mathrm{M}$ & 2840 & 25.54 & 0.90 \\
\hline & $\mathrm{F}$ & 2050 & 25.54 & 1.25 \\
\hline \multirow{2}{*}{ Protein $(\mathrm{g})$} & $\mathrm{M}$ & 73 & 2.24 & 3.07 \\
\hline & $\mathrm{F}$ & 59 & 2.24 & 3.80 \\
\hline \multirow{2}{*}{ Thiamin (mg) } & $\mathrm{M}$ & 1.4 & 0.02 & 1.43 \\
\hline & $\mathrm{F}$ & 1.1 & 0.02 & 1.82 \\
\hline \multirow{2}{*}{ Riboflavin (mg) } & M & 1.5 & 0.01 & 0.36 \\
\hline & $\mathrm{F}$ & 1.1 & 0.01 & 0.49 \\
\hline \multirow{2}{*}{ Niacin (mg) } & $\mathrm{M}$ & 16 & 0.28 & 1.75 \\
\hline & $\mathrm{F}$ & 14 & 0.28 & 2.00 \\
\hline \multirow{2}{*}{ Calcium (mg) } & M & 1000 & 8.57 & 0.86 \\
\hline & $\mathrm{F}$ & 1000 & 8.57 & 0.86 \\
\hline \multirow{2}{*}{ Iron (mg) } & M & 14 & 0.43 & 3.07 \\
\hline & $\mathrm{F}$ & 27 & 0.43 & 1.59 \\
\hline \multirow{2}{*}{ Thiamin (mg) } & $\mathrm{M}$ & 1.4 & 0.33 & 23.57 \\
\hline & $\mathrm{F}$ & 1.1 & 0.33 & 30.00 \\
\hline \multirow{2}{*}{ Riboflavin (mg) } & $\mathrm{M}$ & 1.5 & 1.13 & 75.33 \\
\hline & $\mathrm{F}$ & 1.1 & 1.13 & 102.73 \\
\hline
\end{tabular}

Table 10. Computed Actual Nutrient per Serving of Arroz Caldo and the \% RENI Contribution.

\begin{tabular}{|c|c|c|c|c|}
\hline \multirow{2}{*}{$\begin{array}{l}\text { Calorie and Nutrients } \\
\text { Evaluated }\end{array}$} & \multirow{2}{*}{\multicolumn{2}{|c|}{ RENI }} & \multicolumn{2}{|l|}{ Arroz Caldo } \\
\hline & & & Calorie/NV & \%RENI \\
\hline \multirow{2}{*}{ Calories } & $M$ & 2840 & 37.32 & 1.31 \\
\hline & $\mathrm{F}$ & 2050 & 37.32 & 1.2 \\
\hline \multirow{2}{*}{ Protein (g) } & M & 73 & 1.60 & 2.19 \\
\hline & $\mathrm{F}$ & 59 & 1.60 & 2.71 \\
\hline \multirow{2}{*}{ Thiamin (mg) } & M & 1.4 & 0.09 & 6.43 \\
\hline & $\mathrm{F}$ & 1.1 & 0.09 & 8.18 \\
\hline \multirow{2}{*}{ Riboflavin (mg) } & M & 1.5 & 0.02 & 1.33 \\
\hline & $\mathrm{F}$ & 1.1 & 0.02 & 1.82 \\
\hline \multirow{2}{*}{ Niacin (mg) } & M & 16 & 0.34 & 2.13 \\
\hline & $\mathrm{F}$ & 14 & 0.34 & 2.43 \\
\hline \multirow{2}{*}{ Calcium (mg) } & M & 1000 & 7.86 & 0.79 \\
\hline & $\mathrm{F}$ & 1000 & 7.86 & 0.79 \\
\hline \multirow{2}{*}{ Iron (mg) } & M & 14 & 0.75 & 5.36 \\
\hline & $\mathrm{F}$ & 27 & 0.75 & 2.78 \\
\hline
\end{tabular}

Arroz Caldo was found to have very minimal calorie and nutrient contribution. The table shows that it did not even meet $10 \%$ of the RENI for both sexes. The addition of a piece of egg to a bowl of Arroz Caldo would somehow increase its calorie and nutritive values. As observed, only a few students order it with a piece of egg.

Table 11 presents the comparison among the ten (10) snack items. It could be noted that almost all of the snacks sold in the university are deficient in nutrients when taken singly and in the usual serving portion.

The result of the study runs counter to the findings as Bliss (2012) states that snacks provide about one-third (32 percent for women and 31 percent for men) of all daily calories come from "empty calories," which are calories from solid fats and added sugars (food components that provide little nutritional value).Nonetheless, the results also show that the fat level of most snacks fall below the expected fat make up of no more than 30 percent of the diet. 


\subsection{Concentrated Sources of Calories and Nutrients}

The ten snack items were assessed as to their level of calories and nutrient contents. Results show that Bihon Guisado and Spgahetti contributed the highest calorie content with 307 and 268 calories, respectively.

For the protein level, Footlong, Hotdog and Spaghetti contain 11.64grams, 8.71 grams, 2.08 grams, respectively. Spaghetti's protein content is contributed mainly by the ground meat as one of the major ingredients.

In terms of the thiamin content of the snacks, Pancit Guisado ranks first with $4.56 \mathrm{mg}$ of thiamine. In the case of riboflavin, Hotdog on Stick has the highest riboflavin level with $1.13 \mathrm{mg}$.

The three most concentrated sources of niacin among the ten snack items are Spaghetti, Pancit Guisado, and Mami with levels $1.90 \mathrm{mg}$. $1.60 \mathrm{mg}$ and $1.52 \mathrm{mg}$, respectively.

Mineral contents evaluated include calcium and iron. This time Footlong ranked first as the most concentrated source of niacin with $4.98 \mathrm{mg}$. This was seconded by Spaghetti with $4.90 \mathrm{mg}$. Hotdog on Stick has $37.25 \mathrm{mg}$ of calcium.

This time, it is Macaroni Soup which is identified as the most concentrated source of iron with $5.62 \mathrm{mg}$ per serving.

\subsection{Nutritional Adequacy of the Students' Main Meals}

Table 12 shows the proximate composition of the meals consumed regularly by the customers ranging from ricevegetable-rice-meat/fish, and rice-meat/fish-vegetable combinations.

Results show that rice-meat-vegetable and rice-meat combinations meet at least $20 \%$ of the RENI for protein for both sexes. Calories, carbohydrates and fats are all below $20 \%$ of the RENI. Height and physical activity affect the calorie and nutritional requirements of individuals. The higher and the more active you are, the higher is the RENI.

Table 11. Vegetable-Rice Combination.

\begin{tabular}{|c|c|c|c|c|c|c|}
\hline \multicolumn{2}{|c|}{ Food Item } & Amount & Carbs(g) & Prot.(g) & Fats(g) & Calories \\
\hline \multicolumn{2}{|l|}{$\begin{array}{l}\text { Vegetable } \\
\text { Dish }\end{array}$} & $1 / 2$ cup & 3 & 1 & - & 16 \\
\hline \multicolumn{2}{|l|}{ Rice } & $3 / 4$ cup & 34.5 & 3 & 0 & 150 \\
\hline \multicolumn{2}{|l|}{$\begin{array}{l}\text { Fat for } \\
\text { vegetable }\end{array}$} & $1 \mathrm{t}$ & - & - & 5 & 45 \\
\hline \multicolumn{2}{|l|}{ TOTAL } & & 37.5 & 4 & 5 & 211 \\
\hline \multirow{2}{*}{ RENI } & $\mathrm{M}$ & & & 73 & & 2840 \\
\hline & F & & & 59 & & 2050 \\
\hline \multirow{2}{*}{$\begin{array}{l}\% \text { RENI } \\
\text { Cont }\end{array}$} & $\mathrm{M}$ & & & 5.48 & & 5.85 \\
\hline & $\mathrm{F}$ & & & 7.40 & & 8.10 \\
\hline
\end{tabular}

Table 11 shows that vegetable-rice combination is "inadequate" to meet at least $20 \%$ of the RENI for protein and calories. Carbohydrate content of the meal is only 37.5 grams while its fat content is 5 grams.
Table 12. Calorie and Nutritive Value of Students' Main Meals Rice-MeatVegetable Combination.

\begin{tabular}{|c|c|c|c|c|c|c|}
\hline \multicolumn{2}{|c|}{ Food Item } & Amount & Carbs(g) & Prot.(g) & Fats(g) & Calories \\
\hline \multicolumn{2}{|l|}{$\begin{array}{l}\text { Vegetable } \\
\text { Dish }\end{array}$} & $1 / 2$ cup & 3 & 1 & - & 16 \\
\hline \multicolumn{2}{|l|}{ Rice } & $3 / 4$ cup & 34.5 & 3 & & 150 \\
\hline \multicolumn{2}{|l|}{ Meat } & $1 \mathrm{mbx}$ & - & 8 & 4 & 68 \\
\hline \multicolumn{2}{|l|}{ Fat } & $1 \mathrm{t}$ & - & - & 5 & 45 \\
\hline \multicolumn{2}{|l|}{ TOTAL } & & 37.5 & 12 & 9 & 279 \\
\hline \multirow{2}{*}{ RENI } & M & & & 73 & & 2840 \\
\hline & $\mathrm{F}$ & & & 59 & & 2050 \\
\hline \multirow{2}{*}{$\%$ RENI } & $\mathrm{M}$ & & & 16.44 & & 9.82 \\
\hline & $\mathrm{F}$ & & & 21.43 & & 13.61 \\
\hline
\end{tabular}

Table 12 shows that vegetable-rice-meat combination supplies more than one-fifth of the protein requirement for female. Doubling the amount of the rice and meat exchanges would be adequate to meet the $20 \%$ of the calorie and protein requirements for both sexes.

Table 13. Calorie and Nutritive Value of Students' Main Meal: Rice-Meat Combination.

\begin{tabular}{lllllll}
\hline Food Item & Amount & Carbs(g) & Prot.(g) & Fats(g) & Calories \\
\hline Rice & $3 / 4$ cup & 34.5 & 3 & 0 & 150 \\
Meat & $1 \mathrm{mbx}$ & - & 8 & 4 & 68 \\
TOTAL & & & 34.5 & 11 & 4 & 166 \\
RENI & M & & & 73 & & 2840 \\
& F & & & 59 & & 2050 \\
\%RENI & M & & & 15.07 & & 7.68 \\
& F & & & 18.64 & & 10.73 \\
\hline
\end{tabular}

A student meal consisting of a slice of meat and threefourths cup of boiled rice is insufficient to meet the $20 \%$ of the recommended calorie and protein intakes for both sexes. Doubling the serving portion for meat and rice is more than enough to meet at least $20 \%$ of the recommended intakes. In a study conducted by Turconi (2008) on the nutritional adequacy of Primary School canteen menus, the menus offered appeared nutritionally adequate but portion sizes were often too big for the children's age. Consequently a lot of waste was encountered, especially fruit and vegetables (70\% of children refused vegetables), but first and main courses were also wasted $(50 \%$ of children consumed a first course and the same proportion consumed a main course). The meals offered by the school canteens appeared nutritionally appropriate although portion-sizes were often too large for 7-8.5 aged schoolchildren. The quality and variety of the menus were good.

In the study on the Nutritional profile of foods offered and consumed in a Belgian university canteen, Lachat, et.al (2009) found out that only $5 \%$ of the mea combinations available and consumed complied with the three basic dietary recommendations for a hot lunch. The nutritional profile of the meals consumed was in line with that of the meals available.

Of the three meal combinations, rice-meat-vegetable, considered as a complete meal, is still found inadequate for the age group under study. While the rest would opt to increase their food intake by adding servings of the meals, 
majority are taking the usual serving portion the canteen offers for a meal.

\subsection{Proposed Program/Project for Implementation}

With the findings of the study, the following proposal is devised with the end in view of improving the services of the school canteen.

\subsubsection{Project Title: Greening the University Canteens: Commitment to Health Promotion}

Rationale:

School canteens and other school food services are important educational resources. They have important roles in the provision of food to students and the school community as well as being an integral part of the school environment. The school canteen should reflect the educational goals of the school and support and complement student learning. When consumed daily, the food provided through the school canteen may comprise a third of a student's total daily intake and have a significant influence on their health and nutrition. It is important that administrators, faculty and students work together to support a whole-school approach to building a school culture in which students actively choose nutritious foods and a healthy lifestyle.

\subsubsection{Project Objectives}

The major purpose of this project is to arm the food service operators and workers with the knowledge and skills important in managing a food service. Important learnings acquired in this program will enable them to improve the operation of their food services by providing nourishing, sanitary and affordable meals.

Specifically, the program aims to achieve the following objectives:

(1) To apply sound food, nutrition and health principles in the planning and preparation of meals.

(2) To prepare, cook, store and serve food using techniques to achieve suitable color, flavor and texture while maintaining nutritive values of foods.

(3) To practice personal hygiene, sanitation and safety in the food service.

\subsubsection{Processes to Include}

I. Initial Activities

A. Proposing for the formation of canteen evaluation committee

B. Gathering resources and getting assistance

C. Raising awareness and knowledge

D. Evaluating current status

II. Planning

A. Developing a policy

B. Planning for change

III. Implementation

A. Introducing healthier choices

1. Guide to Good Nutrition

2. Menu Planning

3. Food Presentation, Garnish and Decoration

4. Grooming and Personal Hygiene
5. Good Manufacturing Practices

6. Safety and Sanitation in the Food Service

7. Conduct of Nutrition and Health Researches Among Students, Faculty and Personnel

B. Making Changes successful and Sustainable

IV. Evaluation and Monitoring

A. Getting feedback

B. Reviewing the school canteen policy

C. Communicating Success

\section{Conclusions}

a. Almost all of the snack items evaluated is "less than adequate" for it did not meet at least $20 \%$ of the calorie and nutrient requirements of adolescents aged 16-18 years old. Of the ten snack items, Macaroni Soup has the highest riboflavin and iron contents.

b. The most concentrated sources of calories, protein, thiamin, riboflavin, niacin, calcium and iron are Bihon Guisado, Footlong, Pancit Guisado, Hotdog, Spaghetti, Foot long and Macaroni Soup, respectively.

c. The main meal of the students, specifically lunch, are deficient in quantities considering their RENI. Increasing the quantity for these food combinations to at least $100 \%$ from the usual serving size is enough to meet at least $20 \%$ of the calorie and most of the nutrients under study.

d. There is a heightened need for the canteen operators and food service workers or canteen staff to attend the training program designed to empower these people on proper nutrition, proper food preparation and service, food sanitation standards, etc.

\section{Recommendations}

a. Enhancement and enrichment of the recipes being prepared is needed to make the snack items more concentrated in major nutrients needed for growth and development by the adolescents.

b. Regular monitoring of the canteens' processes and procedures especially in the area of food preparation, service and storage is required.

c. The stall owners should be knowledgeable about healthy food and diet, scientific food service management, food sanitation and safety, personal hygiene, hence the need for training program to equip the food service workers with the knowledge and skills needed to improve the university canteen food service.

d. There should be periodic evaluation of the nutritional values of the foods served to the students as well as periodic evaluation of actual food intake to further improve the food service.

e. Foods for sale must be prepared properly following the strict standards of sanitation and hygiene.

f. Strict policies on food service management by the university must be drafted and implemented for a healthy studentry. 


\section{References}

[1] Avena, Ennata M. (1997) The Philippine Food Composition Tables. Food and Nutrition Research Institute Gen. Santos Ave., Bicutan Tagig City, Philippines.

[2] Academy of Diabetics (2012). Studies Highlighting The Benefits of Snacking. Retrieved on August 24, 2012 from http://www.snacksense.com/healthy-snacking/studieshighlighting-benefits-snacking

[3] American Academy of Pediatrics (2012). Healthy Children Organization. Retrieved on August 24, 2012 from http://www.Caring for Your Teenager (Copyright (C) 2003 American Academy of Pediatrics).

[4] Bliss, R. M. (2012).Snacking Associated with Increased Calories, Decreased Nutrients. Retrieved on August 24, 2012 from http://www.ars.usda.gov/is/pr/2012/120312.htm

[5] Claudio, Serraon Virginia, Moninia S Oliveros; Gemma P Dimaano, Basic Nutrition for Filipinos. Manila: Merriam School \& Office Supplies: Exclusively distributed by Webster School \& Office Supplies, C1982.

[6] Diamond JJ. (2007) Development of a reliable and construct valid measure of nutritional literacy in adults. Nutrition Journal. Retrieved on March 8, 2012 from http://www.nutritionj.com/content/6/1/5.

[7] Dietary References Intakes for Energy, Carbohydrates, Fiber, Fats and Fatty Acids, Cholesterol, Protein and Amino Acids (macronutrients). Retrieved on August 8, 2012 from http://www.map.edu/openbook.php?record_id=6188page. html

[8] Frias, Magdalena, et. al. "Nutrient Intake Adequacy in Schoolchildren from a Mediterranean Area (Southern Spain). Influence of the Use of the School Canteen." International Journal for Vitamin and Nutrition Research, 75(5), pp. 312319.

[9] Gordon, A. (2000), Study of School Motivation Dietary Assessment. Groper, Sarah S. (2007) Advanced Nutrition \& Human Metabolism, 5th edition, Wadsworth Publishing.

[10] Hodgson JM, Hsu-Hage B \& Wahlqvist ML (1994): Food variety as a quantitative descriptor of food intake. Ecology of Food and Nutrition 32, $137 \pm 148$.

[11] Hsu-Hage B \& Wahlqvist ML (1996): Food variety of adult Melbourne chinese: a case study of population in transition. World Rev. Nutr. Diet. 79, $53 \pm 69$.

[12] JJ. (2007)Development of a reliable and construct valid measure of nutritional literacy in adults. Nutrition Journal. Retrieved on March 8, 2012 from http://www.nutritionj.com/content/6/1/5.

[13] Krebs-Smith SM, Smiciklas-Wright H, Guthrie HA \& KrebsSmith J (1987): The effects of variety in food choices on dietary quality. J. Am. Diet. Assoc. 87, $897 \pm 902$.

[14] Lachat, Carl, Lieven F Huybregts ${ }^{\mathrm{a} 2}$, Dominique A Roberfroid $^{\text {a1 }}$, John Van Camp ${ }^{\mathrm{a} 2}$, Anne-Marie E Remaut-De Winter' Petra Debruyne ${ }^{\mathrm{a} 3}$ and Patrick W Kolsteren Nutritional profile of foods offered and consumed in a Belgian university canteen, Journal of Food Science, 2009.

[15] Madden JP, Goodman SJ \& Guthrie HA (1976): Validity of the 24-hr recall. Analysis of data obtained from elderly subjects. J. Am. Diet. Assoc. 68, $143 \pm 147$.

[16] Murphy, S. P., Ph. D, R. D, (2003) USDA Dietary Patterns and Nutritional Adequacy.

[17] National Academy Press: "Dietary Reference Intakes for Energy, Carbohydrate, Fiber, Fat, Fatty Acids, Cholesterol, Protein, and Amino Acids (Macronutrients)," 1st ed. Washington, DC: National pp 207-267, 465-608, 2002. Retrieved on August 25, 2012 from http://www1.fnri.dost.gov.ph - Philippine Food Exchange Lists

[18] Roth Ruth A. Nutrition \& Diet Therapy, Tenth Edition. Delmar Cenage Publishing, 2013.

[19] Schuette LK, Song WO \& Hoerr SL (1996): Quantitative use of the Food Guide Pyramid to evaluate dietary intake of college students. J. Am. Diet. Assoc. 96, $453 \pm 457$.

[20] The Philippine Food Composition Tables (1997) Manila: Department of Science and Technology, Food and Nutrition Research Institute.

[21] Turconi, Giovanna, Lidia Testa, Stefania Moro, Miriam Rossi, Carla Roggi and Laura Maccarini (2008) Acceptability, Waste and Nutritional Adequacy of Primary School Canteen Menus: An Observational Study in Pavia, Northern Italy. Journal of Nutrition and Foods. 